\title{
The Vertical Soft Tissue Thickness and Subcrestal Implant Placement as Factors for Peri-implant Crestal bone Stability
}

\author{
Darko Veljanovski $^{1 *}$ D , Aneta Atanasovska-Stojanovska ${ }^{2}$, Aleksandra Pivkova-Veljanovska $^{3}$, Eitan Mijiritsky $^{4}$ (D), Curd Bollen ${ }^{5}$ \\ ${ }^{1}$ Optimum Dental Clinic, Skopje, Macedonia; ${ }^{2}$ Department of Oral Pathology and Periodontology, Faculty of Dentistry, Universty \\ "Ss.Cyril and Methodius", Skopje, Macedonia; ${ }^{3}$ University Clinic for Hematology, Medical Faculty, University "Ss. Cyril and \\ Methodius", Skopje, Macedonia; ${ }^{4}$ Department of Prosthodontics, School of Dental Medicine, Tel-Aviv University, Tel-Aviv, \\ Israel; ${ }^{5}$ Department of Implant Dentistry, College of Medicine and Dentistry, Ulster University, Birmingham, UK
}

Edited by: Aleksandar Iliev Citation: Veljanovski D, Atanasovska-Stojanovska $A$ Pivkova-Veljanovska A, Mijiritsky E, Bollen C. The Vertica Soft Tissue Thickness and Subcrestal Implant Placement as Factors for Peri-implant Crestalbone stability. Open
Access Maced J Med Sci. 2021 Nov 03; 9(D):257-263 https://doi.org/10.3889/oamjms.2021.6605 Keywords: Vertical soft tissue thickness; Subcrestal implant placement; Bone loss
*Correspondence: Darko Veljanovski, Optimum Dental Clinic, Skopje, Macedonia.
E-mail: darkoveljanovski@gmail.com Received: 08-Jun-2021 Revised: 03-Aug-2021 Copyright: ๑ 2021 Darko Veljanovski, Anet Anasovska-Stojanovska, Aleksandra PivkovaVelijanovska, Eitan Mijijitsky, Curd Bollen Funding: This research did not receive any financial Competing Interests: The authors have declared that no competing interests exis Open Access: This is an open-access article distribute under the terms of the Creative Commons Attribution-

\begin{abstract}
AIM: The aim of this prospective study was to determine the influence of vertical soft tissue thickness on bone level changes in platform-switched implants placed eqicrestally or subcrestally and restored with screw-retained or cement-retained restorations.

METHODS: Platform-switched bone-level implants were placed in a single stage manner in the posterior mandibular region. Implant sites were divided into thick (control) and thin (test) vertical soft tissue groups. The implants in the control group were placed equicrestally. The implant sites from the control group were randomly allocated to receive equicrestally or subcrestally placed implants. Bone remodeling/loss was radiographically measured at baseline, three months postoperatively and six months after delivery of final prosthetic restoration.

RESULTS: The mean crestal bone loss values three months postoperatively and six months post prosthetic restoration were higher in sites with thin versus sites with thick gingiva. In implant sites with thin gingiva, subcrestally placed implants presented less bone loss than eqicrestally placed implants.

CONCLUSION: Platform switched implants are prone to more bone loss when they are placed in sites with thin soft tissue, regardless of the type of final restoration (screw- retained or cement-retained). Subcrestal placement of platform-switched implants can prevent crestal bone loss in sites with vertical soft tissue thickness $<3 \mathrm{~mm}$.
\end{abstract}

\section{Introduction}

The stable peri-implant crestal bone is one of the most desired outcomes in implant dentistry [1]. Peri-implant crestal bone loss $<1.5 \mathrm{~mm}$ was defined as a reference point for successful implant treatment after 1 year of loading [2]. However, this concept needs redefining with the use of new implant designs, surface technologies, and new research on factors affecting bone remodelling [3]. $1.5 \mathrm{~mm}$ of bone loss is no longer acceptable during the $1^{\text {st }}$ year in function. According to one clinical trial, $96 \%$ of implants with bone loss $>2 \mathrm{~mm}$ during the first 18 months presented with mean $0.44 \mathrm{~mm}$ bone loss 6 months post loading [4]. Many factors contribute to bone loss: Inadequate occlusion, the presence of a microgap, use of an implant with a smooth collar, infection, and more importantly, soft tissue thickness and its influence during re-establishment of the biologic width [5], [6], [7], [8], [9].

Crestal bone level changes around dental implants may be presented as bone remodeling (controlled bone loss that stops at the level at the prosthetic implants platform) and progressive bone loss - bone remodeling that continues past the implant neck, which becomes exposed to soft tissue. Progressive bone loss around the implant neck leads to peri-implantitis development. Therefore, minimizing or preventing this initial bone remodeling is of paramount importance, starting at the time of implant placement. Different methods have been proposed to minimize bone loss: Platform switching, different apicocoronal positions of the implant with regard to the alveolar crest, and laser-modified implant surfaces [10], [11], [12].

The aim of this prospective study was to determine the influence of vertical soft tissue thickness on bone level changes in implants with platform - switched design placed at different apicocoronal positions in regard to the bone crest and restored with screwretained and cement-retained restorations.

\section{Methods}

Fifty-two bone-level implants with platformswitched design (Implantswiss, Novodent SA 
Yverdon-les-Bains, Swiss) were placed in a single stage manner (with simultaneously connected healing abutment) in 38 patients. The patients included in the study were at least 18 years old with no medical contraindication for implant surgery. Additional inclusion criteria were missing teeth in the posterior lower jaw; at least $6 \mathrm{~mm}$ bone width and $8 \mathrm{~mm}$ bone height; periodontal health: Bleeding on probing $(\mathrm{BOP})<20 \%$, periodontal index $(\mathrm{PI})<25 \%$; a minimum of $4 \mathrm{~mm}$ keratinized gingiva buccolingually; no bone augmentation procedures before or during implant placement, and primary implant stability of $35 \mathrm{Ncm}$ to allow single - stage surgery. After administration of local anesthesia, (1.8 $\mathrm{ml}$ 2\% Mepivacaine, Scandonest Special, Septodont, Saint-Maur-des-Fosses, France), a midcrestal incision was done to preserve the attached mucosa. A full- thickness buccal flap was raised, and the vertical soft tissue thickness was measured with a $1.0 \mathrm{~mm}$ marked periodontal probe (UNC, Hu-Friedy, Chicago, IL, USA), vertically positioned before lingual flap was raised (Figure 1).

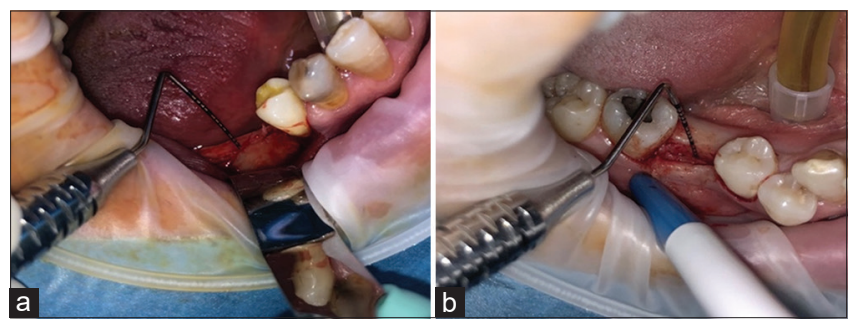

Figure 1: ( $a$ and b) Vertical soft tissue thickness: Thin versus thick

Implant sites were divided into two groups: Implant sites with gingival thickness of $3 \mathrm{~mm}$ or more (control group) and implant sites with gingival thickness of $<3 \mathrm{~mm}$ (test group). After the measurement, the lingual full-thickness flap was elevated, and the site for implant placement was prepared. The osteotomy site was at least $1.5 \mathrm{~mm}$ from the adjacent tooth/teeth, and there was at least $1 \mathrm{~mm}$ of space between the buccal and lingual crests of the alveolar ridge and implant. The implants in the control group were places equally to the bone crest level (equicrestally), whereas the sites from the control group were randomly allocated to receive equicrestally or subcrestally (below bone crest level) placed implants. The subcrestal implant placement was done using a final osteotomy drill longer by $2 \mathrm{~mm}$

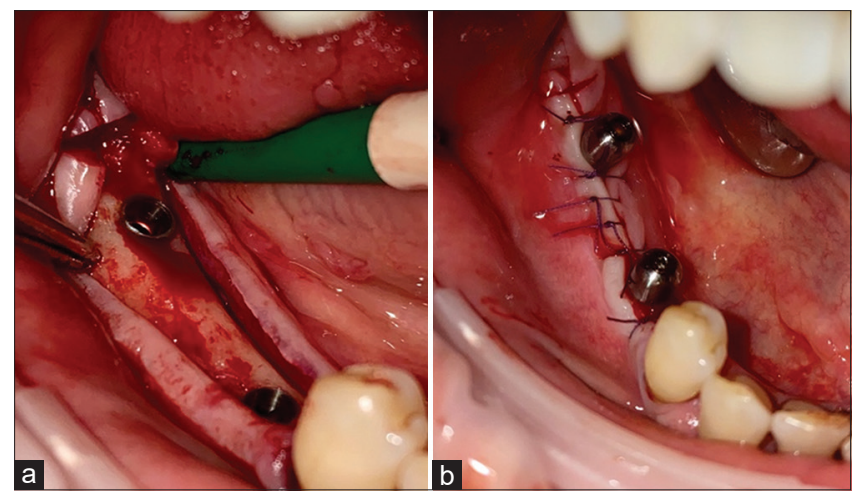

Figure 2: (a and b) Implantswiss "bone-level" implant placement in single-stage manner than the prescribed implant length. The primary and the secondary implant stability were determined using an implant stability quotient (ISQ) instrument (Penquin ISQ, Gothenborg, Sweden). After implant insertion, healing abutments were placed and flaps were closed with 5/0 interrupted absorbable sutures (Assucryl, Assut Medical, Pully/Lausanne, Swiss) (Figures 2 and 3). The patients were given postoperative oral hygiene instructions.

Radiographs were taken in high resolution mode with Vario DG X-ray and Xios AE sensor (Denstply Sirona, New York, USA) using a Rinn-like film holder and utilizing the paralleling intraoral radiographic technique. Bone remodeling/loss was measured as a distance (in millimeters) between the implant edge and the first radiological contact between implant and bone at two reference points at mesial and distal implant side. The measurements were done using the digital software Sidexis 4 (Denstply Sirona, New York, USA) at baseline, 3 months postoperatively and 6 months after delivery of final prosthetic restoration (Figure 4). Implants were restored with metal ceramic screw-retained or cemented restorations using long-term temporary cement (Dentotemp, Itena Clinical, Vilepinte, France). All patients underwent 2-month follow-up examinations for periodontal health control.

Data were analyzed using statistical software Prism 9.0 with the implant as a statistical unit. Descriptive statistics, including means, SEs, medians, and ranges of measurements, were calculated. Multiple testing correction analysis was performed using twoway ANOVA. According to the acquired measurement values of bone loss extent, data were distributed into four groups: Bone loss $>1.5 \mathrm{~mm}, 1.01-1.5 \mathrm{~mm}$, 0.51-1 mm, 0-0.5 mm. The mean differences were considered statistically significant at $p<0.05$.

\section{Results}

After 3 months of healing, clinical stability of implants was evaluated. Implants were considered successfully osseointegrated if they presented ISQ

Table 1: Patient and implant characteristics

\begin{tabular}{ll}
\hline Parameters & $\mathrm{n}(\%)$ \\
\hline Number & $38(100)$ \\
Sex & $14(37)$ \\
$\quad$ Males & $24(63)$ \\
$\quad$ Females & \\
Smoking habit & $17(44)$ \\
$\quad$ Non - smoker & $21(56)$ \\
$\quad<10$ cigarettes/day & \\
Median age & $52(25-81)$ \\
$20-40$ years & $11(29)$ \\
$41-60$ years & $14(37)$ \\
$>60$ years & $13(34)$ \\
Number of implants & $52(100)$ \\
Type of placement & $26(50)$ \\
Equicrestal & $26(50)$ \\
Subcrestal & \\
Type of restoration & $27(52)$ \\
Screw-retained & $25(48)$ \\
Cement-retained & \\
\hline
\end{tabular}



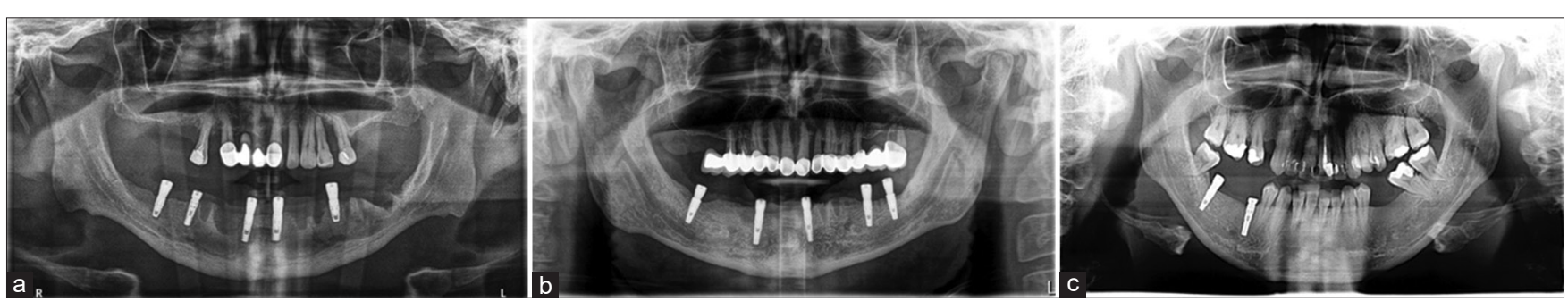

Figure 3: (a-c) Post-operative panoramic images

values above 60 , were clinically immobile, showed no evident radiolucencies, and the patients reported no pain. The sample size included 38 patients (14 males and 24 females) with a mean age 52 (range 25-81). Equal number of implants (26) were placed equicrestally and subcrestally. 27 implants were restored with screw retained and 25 with cement-retained restorations (Table 1). The mean, the median values of vertical soft tissue thickness, as well as the distribution of the vertical soft tissue thickness were calculated (Figure 5).

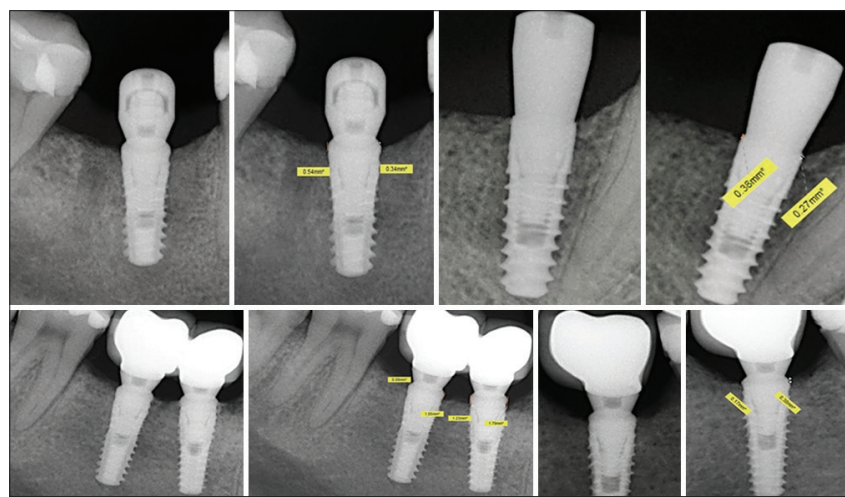

Figure 4: Radiographic measurement of bone loss at different time points

Crestal bone losses at 3 months postoperatively and 6 months post prosthetic restoration in implant sites with vertically thin and thick tissues are given

Table 2: Bone loss $(\mathrm{mm})$ in implant sites with thin and thick gingiva at different time points

\begin{tabular}{|c|c|c|c|c|c|}
\hline & mean & max value & min value & MD & SD \\
\hline \multicolumn{6}{|l|}{$\begin{array}{l}\text { vertically thin } \\
\text { gingiva }\end{array}$} \\
\hline after 3 months & 1,42 & 2,80 & & 2,71 & 0,70 \\
\hline $\begin{array}{l}6 \text { months after } \\
\text { prosthetic rest. }\end{array}$ & 1,67 & 3,0 & 0,09 & 3,0 & 0,74 \\
\hline \multicolumn{6}{|l|}{$\begin{array}{l}\text { vertically thick } \\
\text { gingiva }\end{array}$} \\
\hline after 3 months & 0,62 & 2,9 & 0,0 & 2,90 & 0,55 \\
\hline $\begin{array}{l}6 \text { months after } \\
\text { prosthetic rest. }\end{array}$ & 0,72 & 2,85 & 0,17 & 0,72 & 0,56 \\
\hline
\end{tabular}

Table 3: Statistical analysis of mean bone loss values $(\mathrm{mm})$ in thin and thick gingiva at different time point

\begin{tabular}{|cccc|}
\hline $\begin{array}{c}\text { "Tukey's multiple comparisons test" } \\
\text { vertical soft tissue thickness }\end{array}$ & mean & $95 \%$ Cl differences & p-value \\
\hline months thin/ 6 months thin & $-0,2517$ & $-0,5076-0,004259$ & 0,0558 \\
3 months thin/ 3 months thick & 0,7973 & $0,5338-1,061$ & $<0,0001$ \\
3 months thin/ 6 months thick & 0,6983 & $0,4348-0,9618$ & $<0,0001$ \\
6 months thin/ 3 months thick & 1,049 & $0,7854-1,312$ & $<0,0001$ \\
6 months thin/ 6 months thick & 0,9499 & $0,6864-1,213$ & $<0,0001$ \\
3 months thick/ 6 months thick & $-0,09900$ & $0,3650-0,1670$ & 0,7684 \\
\hline
\end{tabular}

Table 4: Bone loss $(\mathrm{mm})$ in vertically thin gingiva depending on implant placement type

\begin{tabular}{|c|c|c|c|c|c|}
\hline & mean & $\max$ value & $\min$ value & MD & SD \\
\hline after 3 months & 0,82 & 1,77 & 1,77 & 1,77 & 0,49 \\
\hline $\begin{array}{c}6 \text { months after } \\
\text { prosthetic rest. } \\
\text { equicrestal }\end{array}$ & 0,98 & 1,9 & 0,30 & 1,60 & 0,51 \\
\hline after 3 months & 1,25 & 2,90 & 0,09 & 2,80 & 0,88 \\
\hline $\begin{array}{l}6 \text { months after } \\
\text { prosthetic rest. }\end{array}$ & 1,44 & 3,09 & 0,09 & 3,00 & 0,98 \\
\hline
\end{tabular}

in Table 2. Tukey's multiple comparison test showed statistical difference between crestal bone loss values in sites with thin and thick gingiva at two measurement time points $(p<0.001)$ (Table 3$)$. Table 4 shows crestal bone losses only in implant sites with thin vertical soft tissue thickness in equicrestally and subcrestally placed implants. Tukey's multiple comparison test again shows high statistical significance between the two groups ( $p$ $<0.001$ ) (Table 5).

Table 5: Statistical analysis of mean bone loss values $(\mathrm{mm})$ in vertically thin gingiva depending on implant placement type

\begin{tabular}{|lccc|}
\hline \multicolumn{1}{|c}{$\begin{array}{c}\text { "Tukey's multiple comparisons test" } \\
\text { subcrestal vs. equicrestal }\end{array}$} & mean & $95 \%$ Cl differences & $p$-value \\
\hline m months mesial subcrestal/ 3 months mesial equicrestal & 0,8898 & $-0,313-0,467$ & $<0,0001$ \\
3 months distal subcrestal/3 months distal equicrestal & $-0,7808$ & $-1204-0,3580$ & $<0,0001$ \\
6 months mesial subcrestal/ 6 months mesial equicrestal & $-1,072$ & $1,494-0,6487$ & $<0,0001$ \\
6 months. distal subcrestal/ 6 months distal equicrestal & $-0,7825$ & $-1,205-0,3597$ & $<0,0001$ \\
\hline
\end{tabular}

Table 6 shows crestal bone losses in implants restored with screw retained and cement-retained restorations. No statistically significant difference for

Table 6: Bone loss $(\mathrm{mm})$ in vertically thin gingiva depending on implant - prosthetic restoration connection type

\begin{tabular}{|c|c|c|c|c|c|}
\hline screw - retained & mean & max value & min value & MD & SD \\
\hline after 3 months & 1,39 & 2,8 & & 2,7 & 0,80 \\
\hline $\begin{array}{l}6 \text { months after } \\
\text { prosthetic rest. } \\
\cdot \cdot \\
\text { cement - retained }\end{array}$ & 1,62 & 3,09 & 0,09 & 3,00 & 0,84 \\
\hline after 3 months & 1,52 & 2,40 & 0,40 & 2,00 & 0,59 \\
\hline $\begin{array}{l}6 \text { months after } \\
\text { prosthetic rest. }\end{array}$ & 1,81 & 2,80 & 0,45 & 2,35 & 0,64 \\
\hline
\end{tabular}




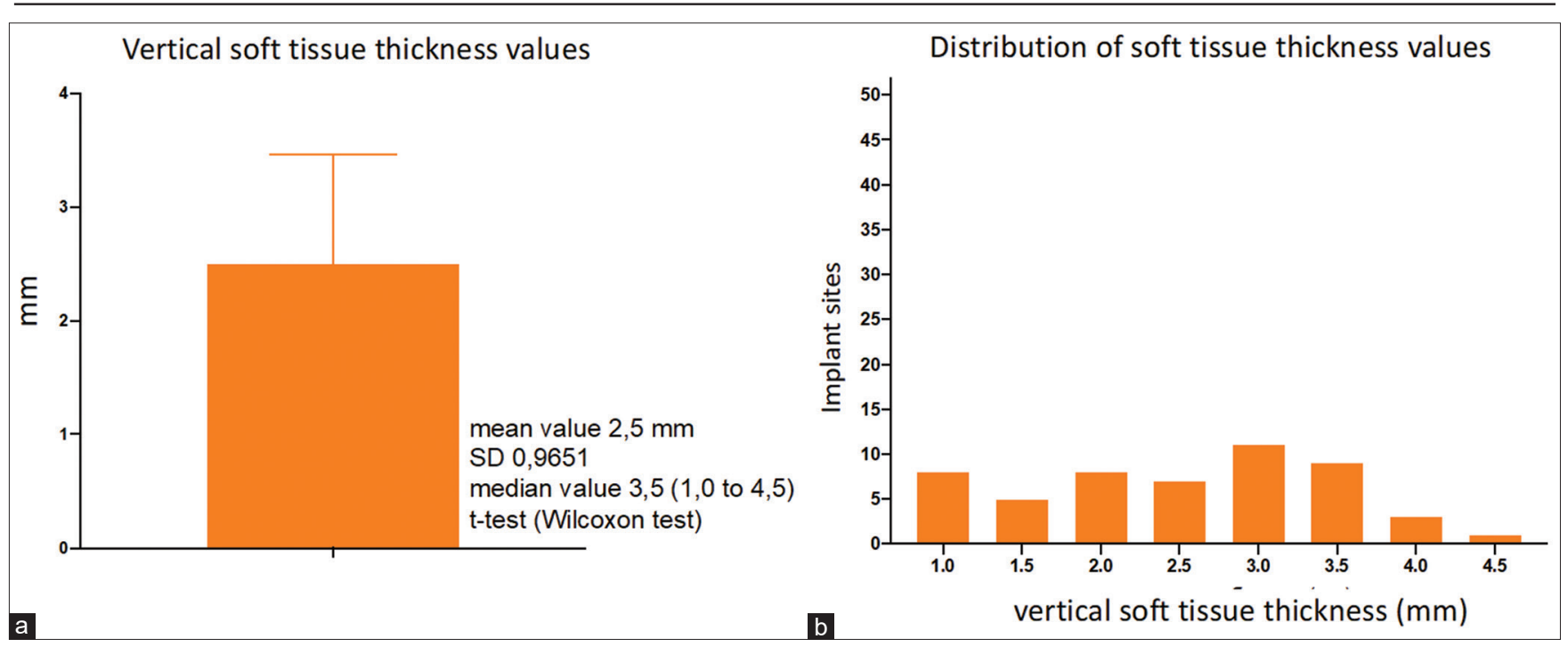

Figure 5: (a and b) Mean, median values and distribution of vertical soft tissue thickness

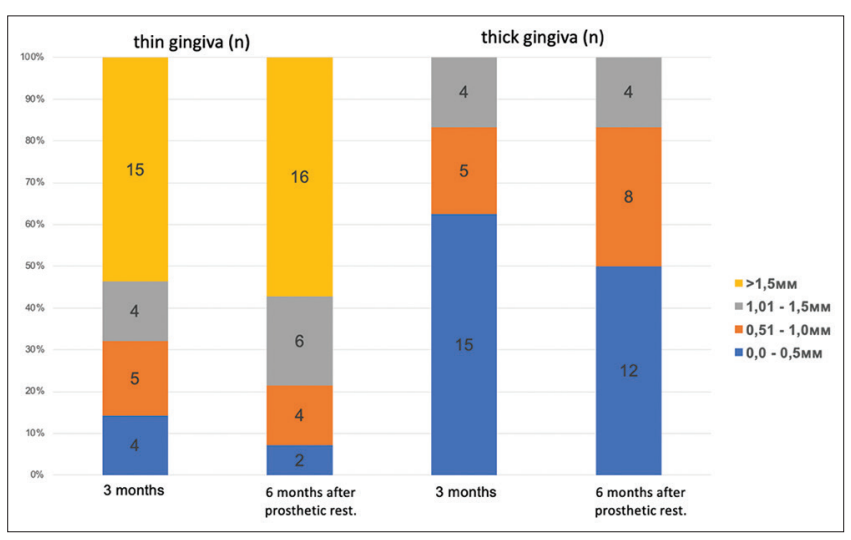

Figure 6: Bone loss distribution in groups

crestal bone loss values was found between the two groups at two measurement time points (Table 7). Figure 6 shows the distribution of bone loss in implants sites with vertically thin and thick tissues.

\section{Discussion}

This study aimed to evaluate the effect of vertical soft tissue thickness on crestal bone loss in platform-switched implants and the subcrestal placement of implants with platform - switched design

Table 7: Statistical analysis of mean bone loss values $(\mathrm{mm})$ in vertically thin gingiva depending on implant - prosthetic restoration connection type

\begin{tabular}{|c|c|c|c|}
\hline 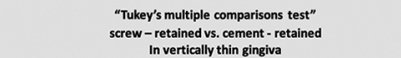 & mean & 95\% Cl differences & p-value \\
\hline 3 months mesial screw - retained / 3 months mesial cement - retained & $-0,03754$ & $-0,6618-0,5871$ & $>0,9999$ \\
\hline 3 months mesial screw - retained / 6 months mesial cement - retained & $-0,1291$ & $-0,7533-0,4951$ & 0,9982 \\
\hline 3 months distal screw - retained / 3 months distal cement - retained & $-0,2089$ & $-0,8331-0,4153$ & 0,9672 \\
\hline 3 months distal screw - retained / 6 months distal cement - retained & $-0,3004$ & $-0,9246-0,3238$ & 0,8083 \\
\hline
\end{tabular}

on crestal bone maintenance in implants sites with thin soft tissues. Statistically significant greater extent of bone loss was found in implant sites with thin tissues in comparison with thick soft tissue sites regardless of the type of connection between the implant and the restoration (screw-retained or cement - retained) and the type of implant placement (subcrestal or equicrestal). The results consistently showed that subcrestally placed implants in sites with thin soft tissue showed significantly less bone loss compared with equicrestally placed implants.

The implant abutment connection is an important factor in the etiology of bone loss because of the presence of the microgap between the implant and the abutment as well as the micromovement that pumps bacterial load in the surrounding tissue. To distance the microgap away from the alveolar bone, several methods have been proposed, such as displacing this implant abutment connection horizontally and vertically [10], [11]. In platformswitched implants, the implant abutment connection is displaced inward, so that the microgap is farther away horizontally from the alveolar bone. The rationale resides in this microgap acting as a reservoir for bacterial colonization, accumulating an inflammatory cell infiltrate that, because of its proximity to the bone, may trigger bone resorption with the negative effect of bacteria and mechanical micromovement [13], [14], [15], [16]. Multiple randomized controlled trials as well as systematic reviews have confirmed its efficacy in maintaining crestal bone [17], [20], [21].

However, many studies failed to demonstrate any significant difference if thin mucosa $(<2 \mathrm{~mm})$ is present [22], [31]. Vandeweghe and DeBruyn concluded that platform switching is effective only when mucosal thickness is sufficient for establishment of biologic width [32]. Galindo-Moreno et al. reported that vertical mismatching in relation with prosthetic abutment height, conditioned clinically by the keratinized mucosa width, is better than platform switching in the preservation of 
crestal bone loss [33]. Several other studies shed light on the potential correlation of peri-implant soft tissue thickness and crestal bone loss [18], [33], [34].

To distance the implant-abutment connection and its negative effect from the crestal bone, bone-level implants can be placed supracrestally and subcrestally. Supracrestal implant placement requires polished implant neck, while subcrestal placement requires stable conical implant abutment connection. Dibart et al. reported that an implant placed at the crestal bone level approximated the microgap to the bone, and bone loss would occur due to possible bacterial leakage [35]. Piattelli et al. suggested that a more apical position of the implant abutment connection implied a higher crestal bone loss than a more coronal position due to closer proximity to the bone of the inflammation zone associated with the implant abutment interface [11]. Subcrestal placement of bone-level implants is recommended with simultaneous use of healing abutments to avoid the unnecessary bone growth over the implant platform. Hermann et al. in a series of animal studies [15] reported extensive bone loss in subrestally placed implants with polished neck and with matching implants abutment connection. Therefore, only implants without polished neck but with stable conical platform-switched connection that distances bacteria from the bone and precludes movement of the abutment platform can be placed subcrestally.

Most studies aiming at minimizing the crestal bone loss lack proper analysis of the mucosal thickness at the time of implant placement [17], [18], [19], [20]. In 1996 , it was demonstrated that if a minimal requirement for biologic width formation is not satisfied, providing enough surface for both junctional epithelium and connective tissue attachments, bone resorption will occur [9]. Galindo-Moreno et al. and Vervaeke et al. concluded that implants with longer abutments had less crestal bone loss. Although both studies lacked measurements of tissue thickness at the time of implant placement, it could be hypothesized that longer abutments correspond with thicker tissues which is why less bone loss is expected [29], [30]. Several clinical trials investigated the influence of soft tissue thickness on initial bone remodeling after implant placement, concluding that if a minimum $2 \mathrm{~mm}$ is not present during stage 1 surgery, bone resorption will occur regardless of the use of laser-microtextured collars and platform-switching connections [22]. Linkevicius, Puisys et al. [23], [24] demonstrated statistically significantly less crestal bone loss when thick tissue or augmented thin tissues were present compared with non-augmented thin tissues. Results from studies from this group showed that tissues with $>2 \mathrm{~mm}$ thickness, as measured perpendicularly from the crest at the time of implant placement, had less bone loss [25], [26], [27], [28].

Although the threshold between thin and thick tissues in most clinical trials is $2 \mathrm{~mm}$, in our study it was $3 \mathrm{~mm}$. This was done because in the clinical trials, highly prevalent issues with medium thickness of $2.5 \mathrm{~mm}$ showed similar values for bone loss with thin tissues (<2 mm). Several studies have already implemented the use of $3 \mathrm{~mm}$ as a minimal tissue thickness to avoid the gingival height in etiology of crestal bone loss [36].

The present study has several limitations. Firstly, the validity of the results might be limited to the posterior mandibular area, and additional studies may be required to evaluate the effect of soft tissue thickness on crestal bone stability in the maxilla. Secondly, the extent of bone loss is measured at mesial and distal reference points, lacking data about vestibular, and lingual implant sides. On the other hand, this study shows that thin soft tissue may predispose bone to significant remodeling around implants with platform switching and that subcrestal implant placement in thin tissue sites may minimize or eliminate crestal bone loss.

\section{Conclusion}

Within the previously mentioned limitations of the study, it can be concluded that vertical soft tissue thickness plays an important role in the etiology of crestal bone loss. The platform switched implants are prone to more bone loss when they are placed in sites with thin soft tissue, regardless of the type of final restoration (screw-retained or cement-retained). Subcrestal placement of platform-switched implants can prevent crestal bone loss in sites with vertical soft tissue thickness $<3 \mathrm{~mm}$.

\section{References}

1. Albrektsson T, Buser D, Sennerby L. Crestal bone loss and ora implants. Clin Implant Dent Relat Res. 2012;14:783-91. https:// doi.org/10.1111/cid.12013

2. Albrektsson T, Zarb G, Worthington P, Eriksson AR. The longterm efficacy of currently used dental implants: A review and proposed criteria of success. Int $\mathrm{J}$ Oral Maxillofac Implants. 1986;1:11-25.

PMid:3527955

3. Albrektsson T, Dahlin C, Jemt T, Sennerby L, Turri A, Wennerberg $A$. Is marginal bone loss around oral implants the result of a provoked foreign body reaction? Clin Implant Dent Relat Res. 2014;16(2):155-165. https://doi.org/10.1111/cid.12142 PMid:24004092

4. Galindo-Moreno P, Leon-Cano A, Ortega-Oller I, Monje A, O'Valle F, Catena A. Marginal bone loss as success criterion in implant dentistry: Beyond $2 \mathrm{~mm}$. Clin Oral Implants Res. 2015;26(4):e28-34. https://doi.org/10.1111/clr.12324 PMid:24383987

5. Misch CE, Dietsh-Misch F, Hoar J, Beck G, Hazen R, Misch CM A bone quality-based implant system: First year of prosthetic loading. J Oral Implantol. 1999;25(3):185-97. https://doi. org/10.1563/1548-1336(1999)025<0185:abqisf>2.3.co;2 
PMid:10551149

6. Hermann JS, Schoolfield JD, Schenk RK, Buser D, Cochran DL. Influence of the size of the microgap on crestal bone changes around titanium implants. A histometric evaluation of unloaded non-submerged implants in the canine mandible. J Periodontol 2001;72(10):1372-83. https://doi.org/10.1902/ jop.2001.72.10.1372

PMid:11699479

7. Wiskott HW, Belser UC. Lack of integration of smooth titanium surfaces: A working hypothesis based on strains generated in the surroundingbone.ClinOrallmplantsRes.1999;10(6):429-44.https:// doi.org/10.1034/j.1600-0501.1999.100601.x

PMid:10740452

8. Barboza EP, Caula AL, Carvalho WR. Crestal bone loss around submerged and exposed unloaded dental implants: A radiographic and microbiological descriptive study. Implant Dent. 2002;11(2):162-9. https://doi. org/10.1097/00008505-200204000-00018

PMid:12078599

9. Berglundh T, Lindhe J. Dimension of the periimplant mucosa. Biological width revisited. J Clin Periodontol. 1996;23(10):971-3. https://doi.org/10.1111/j.1600-051x.1996.tb00520.x PMid:8915028

10. Lazzara RJ, Porter SS. Platform switching: A new concept in implant dentistry for controlling postrestor-ative crestal bone levels. Int J Periodontics Restorative Dent. 2006;26(1):9-17. PMid:16515092

11. Piattelli A, Vrespa G, Petrone G, lezzi G, Annibali S, Scarano A Role of the microgap between implant and abutment: A retrospective histologic evaluation in monkeys. J Periodontol. 2003;74(3):346-52. https://doi.org/10.1902/jop.2003.74.3.346 PMid:12710754

12. Nevins M, Nevins ML, Camelo M, Boyesen JL, Kim DM. Human histologic evidence of a connective tissue attachment to a dental implant. Int J Periodontics Restorative Dent. 2008;28(2):111-21. https://doi.org/10.11607/prd.1848

PMid:18546807

13. Hammerle $\mathrm{CH}$, Bragger $\mathrm{U}$, Burgin $\mathrm{W}$, Lang NP. The effect of subcrestal placement of the polished surface of ITI implants on marginal soft and hard tissues. Clin Oral Implants Res. 1996;7(2):111-9. https://doi. org/10.1034/j.1600-0501.1996.070204.x PMid:9002829

14. Ericsson I, Persson LG, Berglundh T, Marinello CP, Lindhe J, Klinge B. Different types of inflammatory reactions in periimplant soft tissues. J Clin Periodontol 1995;22(3):255-61. https://doi.org/10.1111/j.1600-051x.1995.tb00143.x PMid:7790533

15. Hermann JS, Buser D, Schenk RK, Cochran DL. Crestal bone changes around titanium implants. A histometric evaluation of unloaded non-submerged and submerged implants in the canine mandible. J Periodontol. 2000;71(9):1412-24. https://doi. org/10.1902/jop.2000.71.9.1412

PMid: 11022770

16. Broggini N, McManus LM, Hermann JS, Medina R, Schenk RK, Buser D, et al. Peri-implant inflammation defined by the implantabutment interface. J Dent Res. 2006;85(5):473-8. https://doi. org/10.1177/154405910608500515 PMid:16632764

17. Canullo L, Fedele GR, lannello G, Jepsen S. Platform switching and marginal bone-level alterations: The results of a randomizedcontrolled trial. Clin Oral Implants Res. 2010;21(1):115-21. https://doi.org/10.1111/j.1600-0501.2009.01867.x PMid:20070752
18. Canullo L, lannello G, Penarocha M, Garcia B. Impact of implant diameter on bone level changes around platform switched implants: Preliminary results of 18 months follow-up a prospective randomized match- paired controlled trial. Clin Oral Implants Res. 2012;23(10):1142-6. https://doi. org/10.1111/j.1600-0501.2011.02297.x PMid:22111758

19. Canullo L, lannello G, Gotz W. The influence of individual bone patterns on peri-implant bone loss: Preliminary report from a 3-year randomized clinical and histologic trial in patients treated with implants restored with matching-diameter abutments or the platform-switching concept. Int J Oral Maxillofac Implants. 2011;26(3):618-30. https://doi.org/10.11607/jomi.6954 PMid:21691610

20. Strietzel FP, Neumann K, Hertel M. Impact of platform switching on marginal peri-implant bone-level changes. A systematic review and meta-analysis. Clin Oral Implants Res. 2015;26(3):342-58. https://doi.org/10.1111/clr.12339 PMid:24438506

21. Atieh MA, Ibrahim HM, Atieh AH. Platform switching for marginal bone preservation around dental implants: A systematic review and meta-analysis. J Periodontol. 2010;81(10):1350-66. https:// doi.org/10.1902/jop.2010.100232

PMid:20575657

22. Linkevicius T, Puisys A, Svediene O, Linkevicius R, Linkeviciene L. Radiological comparison of laser-microtextured and platformswitched implants in thin mucosal biotype. Clin Oral Implants Res. 2015;26(5):599-605. https://doi.org/10.1111/clr.12544 PMid:25558894

23. Linkevicius T, Apse P, Grybauskas S, Puisys A. The influence of soft tissue thickness on crestal bone changes around implants: A 1-year prospective con- trolled clinical trial. Int J Oral Maxillofac Implants. 2009;24(4):712-9. https://doi.org/10.1111/clr.12301 PMid:19885413

24. Linkevicius T, Apse P, Grybauskas S, Puisys A. Reaction of crestal bone around implants depending on mucosal tissue thickness. A 1-year prospective clinical study. Stomatologija. 2009;11(3):83-91. https://doi.org/10.1111/clr.12301 PMid:19996674

25. Puisys A, Linkevicius T. The influence of mucosal tissue thickening on crestal bone stability around bone-level implants. A prospective controlled clinical trial. Clin Oral Implants Res. 2015;26(2):123-9. https://doi.org/10.1111/clr.12301 PMid:24313250

26. Linkevicius $T$, Puisys A, Steigmann M, Vindasiute $E$, Linkeviciene L. Influence of vertical soft tissue thickness on crestal bone changes around implants with platform switching: A comparative clinical study. Clin Implant Dent Relat Res. 2015;17(6):1228-36. https://doi.org/10.1111/cid.12222 PMid:24673875

27. Linkevicius T, Puisys A, Linkeviciene L, Peciuliene V, Schlee M. Crestal bone stability around implants with horizontally matching connection after soft tissue thickening: A prospective clinical trial. Clin Implant Dent Relat Res. 2015;17(3):497-508. https:// doi.org/10.1111/cid.12155

PMid:24103157

28. Linkevicius T, Puisys A, Linkevicius R, Alkimavicius J, Gineviciute E, Linkeviciene L. The influence of submerged healing abutment or subcrestal implant placement on soft tissue thickness and crestal bone stability. A 2-year randomized clinical trial. Clin Implant Dent Relat Res. 2020;22:1-10. https://doi. org/10.1111/cid.12903

29. Galindo-Moreno $P$, Leon-Cano A, Ortega-Oller I, Monje A, Suárez F, ÓValle $F$, et al. Prosthetic abutment height is a key factor in peri- implant marginal bone 
loss. J Dent Res. 2014;93(Suppl 7):80S-5. https://doi. org/10.1177/0022034513519800

PMid:24621670

30. Vervaeke S, Dierens M, Besseler J, De Bruyn H. The influence of initial soft tissue thickness on peri-implant bone remodeling. Clin Implant Dent Relat Res. 2014;16(2):238-47. https://doi. org/10.1111/j.1708-8208.2012.00474.x

PMid:22758656

31. Linkevicius T, Apse P, Grybauskas S, Puisys A. Influence of thin mucosal tissues on crestal bone stability around implants with platform switching: A 1-year pilot study. J Oral Maxillofac Surg. 2010;68(9):2272-7. https://doi.org/10.1016/j.joms.2009.08.018 PMid:20605308

32. Vandeweghe S, De Bruyn H. A within-implant comparison to evaluate the concept of platform switching: A randomised controlled trial. Eur J Oral Implantol. 2012;5(3):253-62.

PMid:23000709

33. Galindo-Moreno P, Leon-Cano A, Monje A, Ortega-Oller I, O'Valle F, Catena A. Abutment height influences the effect of platform switching on peri-implant marginal bone loss. Clin Oral Implants Res. 2016;27(2):167-73. https://doi.org/10.1111/clr.12554 PMid:25678247

34. Wiesner G, Esposito M, Worthington H, Schlee M. Connective tissue grafts for thickening peri-implant tissues at implant placement. One-year results from an explanatory split-mouth randomised controlled clinical trial. Eur J Oral Implantol. 2010;3(1):27-35.

PMid:20467596

35. Dibart S, Warbington M, Su MF, Skobe Z. In vitro evaluation of the implant-abutment bacterial seal: The locking taper system. Int J Oral Maxillofac Implants. 2005;20(5):732-7.

PMid:16274147

36. Blanco J, Pico A, Caneiro L, Novoa L, Batalla P, MartinLancharro $P$. Effect of abutment height on interproximal implant bone level in the early healing: A randomized clinical trial. Clin Oral Implants Res. 2018;29(1):108-17. https://doi.org/10.1111/ clr.13108

PMid:29222809 